Рекомендована д. біол. наук, профр. Л. С. Фірою

УДК 615.072:615.322

DOI 10.11603/2312-0967.2017.2.7816

\title{
ЗАБЕЗПЕЧЕННЯ ЯКОСТІ ЛІКАРСЬКИХ ЗАСОБІВ РОСЛИННОГО ПОХОДЖЕННЯ: СТАН ТА ПЕРСПЕКТИВИ
}

\author{
() О. П. Баула, Т. М. Деркач \\ Київський національний університет технологій і дизайну \\ derkach.tm@knutd.com.ua
}

\begin{abstract}
Мета роботи. Аналіз сучасного стану забезпечення якості лікарських засобів рослинного походження, окреслення проблем, що потребують дослідження й опрацювання, та перспективних шляхів їх вирішення.

Матеріали і методи. Лікарська рослинна сировина та лікарські засоби рослинного походження; системний підхід, інорормаційний пошук, статистичні методи, узагальнення та аналіз.

Результати й обговорення. Досліджено сучасні світові підходи до забезпечення якості лікарських засобів рослинного походження порівняно із ситуацією в Україні. Ключовими факторами є забезпечення якості лікарської рослинної сировини за рахунок її стандартизації, а також дотримання вимог належної виробничої практики на всіх етапах виробництва. Побудовано схему, що ілюструє взаємозв'язок між фракторами безпеки та якості, заходами щодо контролю якості та етапами виробництва лікарських засобів рослинного походження.

Висновки. Найважливішими проблемами регулювання обігу лікарських засобів рослинного походження є: створення єдиної класифрікації продуктів, що містять лікарську рослинну сировину; стандартизація сировини (розробка нових методів дослідження вихідної рослинної сировини та забезпечення в ній визначеної концентрації АФІ); відсутність узгоджених підходів до створення системи забезпечення якості лікарських засобів рослинного походження, що повинні охопити усі елементи, які вливають на якість, ефективність та безпеку.
\end{abstract}

Ключові слова: лікарська рослинна сировина; лікарські засоби рослинного походження; стандартизація; якість; забезпечення якості.

Вступ. На сучасному етапі розвитку фрармацевтичної галузі лікарські засоби рослинного походження (ЛЗРП) займають суттєву частину як на національному ринку, так і на провідних ринках світу. За оцінками експертів, близько 25 \% лікарських засобів, що застосовують у медичній практиці в усьому світі, отримують безпосередньо з лікарської рослинної сировини (ЛРС) [1-4].

Традиційно вважають, що ЛЗРП мають низький рівень ризиків щодо безпеки. Споживачі цих препаратів впевнені, що вони мають суттєві переваги над лікарськими засобами синтетичного походження (ЛЗСП), бо є «природними». Більшість ЛЗРП відносять до групи безрецептурних препаратів і споживаються пацієнтами при самолікуванні. Проте деякі ЛЗРП можуть мати серйозні побічні реакції і завдавати шкоди здоров'ю, а інші можуть бути неефективними у боротьбі із хворобами.

Значні ризики ЛЗРП пов'язані з вихідною сировиною, яка внаслідок особливостей отримання може бути контамінована мікроорганізмами, пестицидами, важкими металами. Так, у дослідженні [2] виявлено, що 20 \% ЛЗРП, виготовлених в Індії та Пакистані та розповсюджуваних через Інтернет у США, містили елементи $\mathrm{Pb}$, As та Hg у кількості, що значно перевищували вимоги, зазначені у Фармакопеї США.
Факти забруднення важкими металами досить часто фріксуються у ЛЗРП китайської традиційної медицини. Ряд таких прикладів наведено у роботі [5]. Наприклад, вміст Pb в зразках рослини Radix Codonopsis (женьшень) становив 83,1 мг/кг, а вміст As y Radix Angelicae Sinensis (жіночий женьшень) 23,5 мг/кг, що значно перевищує допустимі межі, встановлені у провідних фрармакопеях світу. Метали можуть по-різному розподілятися між окремими частинами рослин. Так, зразки популярної у китайській медицині рослини Spica Prunellae (чорноголовка звичайна) містять $\mathrm{Pb}, \mathrm{Cd}, \mathrm{Hg}$ і As. Листя серйозно забруднені $\mathrm{Pb}$ i Hg, але коріння містять більше $\mathrm{Cd}$.

Наведені приклади свідчать, що стандартизація ЛРС має важливе значення для забезпечення якості ЛЗРП і є фундаментальною вимогою.

Метою роботи $\epsilon$ аналіз сучасного стану забезпечення якості ЛЗРП та окреслення проблем, що потребують дослідження й опрацювання та перспективних шляхів їх вирішення.

Методи дослідження. Для реалізації мети та поставлених завдань у процесі дослідження використовували методи системного підходу, бібліографрічний, інформаційного пошуку, статистичний, а також узагальнення та аналізу. Для одержання даних щодо ЛзРП використовували Державний

ISSN 2312-0967. Pharmaceutical review. 2017. № 2 
реєстр лікарських засобів України [6] станом на квітень 2017 року.

Результати й обговорення. ЛЗРП широко застосовуються у медичній практиці та можуть використовуватись для лікування тих самих хвороб, що і синтетичні препарати. Але між цими категоріями лікарських засобів є суттєва різниця (табл. 1). До складу синтетичних препаратів входить активний фрармацевтичний інгредієнт (АФІ), якісні та кількісні характеристики якого чітко ідентифіковані та визначені. Разом з тим ЛЗРП завжди містять велику кількість біологічно та хімічно активних сполук, а також мікроелементів, сумарна дія яких визначає терапевтичну активність препарату. Деякі чинники, які не мають суттєвого впливу на якість ЛЗСП, дуже суттєво впливають на ЛЗРП $[7,8]$.

3 даних таблиці 1 видно, що забезпечення якості та ефрективності ЛЗРП за певними параметрами $€$ більш складним, ніж синтетичних препаратів, перш за все з причин природної варіативності складу ЛРС.

Наявні у світі підходи до забезпечення якості ЛЗРП. Впродовж багатьох років ВООЗ аналізує ситуацію в різних країнах та розробляє документи у сфері забезпечення якості ЛЗРП та ЛРС. Опубліковано збірник рекомендованих процедур випробувань для оцінки ідентичності, складу та чистоти ЛРС, «Керівництво з належної виробничої практики культивуван- ня і збору для лікарських рослин». Сорормульована директива щодо принципів оцінки якості ЛЗРП в частині, що стосується забруднюючих речовин та домішок [7-9]. Зазвичай документи ВООЗ мають загальний характер та потребують конкретизації на рівні національного регулювання окремих країн. Для різних регуляторних систем національного рівня характерною є відсутність строгих загальновизнаних вказівок $з$ оцінки безпеки та якості ЛЗРП та ЛРС. Так, в рамках різних регуляторних систем одна і та ж рослина може бути віднесена до харчового продукту, фрункціонального харчового продукту, дієтичної добавки або ЛЗРП.

На національних рівнях існують два принципово різних підходи щодо забезпечення якості ЛЗРП. У багатьох країнах ЛЗРП, що використовуються для діагностики, лікування або профрілактики, розглядаються як лікарські засоби, а усі етапи їх обігу регулюються законодавством у фрармацевтичній ссрері. Типовим прикладом є практика країн ЄС, де з 1995 р. за наукову оцінку та моніторинг безпеки та ефективності лікарських засобів відповідає Європейське агентство з лікарських засобів (ЕМА) [10]. Більшість нових лікарських засобів регулюється через ЕМА. Проте більшість вже існуючих препаратів регулюються на національному рівні. Значну увагу ЕMA приділяє ЛЗРП шляхом регулювання через свій підрозділ - Ко-

Таблиця 1. Порівняння характеристик лікарських засобів рослинного та синтетичного походження

\begin{tabular}{|c|c|c|}
\hline Властивості & ЛЗРП & лЗСП \\
\hline \multicolumn{3}{|c|}{ Фізико-хімічні } \\
\hline AФІ & Часто невідомі & Відомі \\
\hline Наявність чистих АФІ & Рідко & Присутній \\
\hline Наявність сировини & Обмежена & Наявна \\
\hline Стабільність складу & Невизначена & Добра \\
\hline Якість сировини & Може бути нестабільною & Добре відтворювана \\
\hline $\begin{array}{l}\text { Наявність елементних } \\
\text { домішок }\end{array}$ & $\begin{array}{l}\text { Широкий спектр присутніх елементів, } \\
\text { деякі } 3 \text { них обов'язково присутні }\end{array}$ & $\begin{array}{l}\text { Кількість домішок обмежена, } \\
\text { концентрація максимально низька }\end{array}$ \\
\hline Основні джерела домішок & $\begin{array}{l}\text { Біологічне забруднення, ґрунт та } \\
\text { навколишнє середовище }\end{array}$ & $\begin{array}{l}\text { Сировина та побічні продукти синтезу } \\
\text { та каталізу на всіх етапах виробництва }\end{array}$ \\
\hline $\begin{array}{l}\text { Ідентифрікація аналітичними } \\
\text { методами }\end{array}$ & $\begin{array}{l}\text { Ускладнена з причини складності } \\
\text { об'єкта }\end{array}$ & Стандартизована \\
\hline Стандартні зразки & Як правило, відсутні & Наявні \\
\hline \multicolumn{3}{|c|}{ Біомедичні } \\
\hline Механізм дії & Зазвичай невідомий & Зазвичай відомий \\
\hline Токсикологічні тести & Не проведені на тваринах & Обов'язкові \\
\hline Емпіричні дані & Дуже важливі & Часто не мають сенсу \\
\hline Специфрічні побічні ефректи & Зрідка завдяки багаторічному досвіду & Часті \\
\hline $\begin{array}{l}\text { Взаємодія з іншими } \\
\text { лікарськими засобами }\end{array}$ & Зазвичай добра & Обмежена \\
\hline $\begin{array}{l}\text { Доцільність постійного } \\
\text { використання }\end{array}$ & Часто добре вивчена & Невизначена для нових ліків \\
\hline Контроль плацебо & Важко досягнути & Можливо досягнути \\
\hline Клінічні випробування & Зазвичай відсутні & Обов'язкові \\
\hline
\end{tabular}

ISSN 2312-0967. Фармацевтичний часопис. 2017. № 2 
мітет 3 лікарських засобів рослинного походження (HMPC). НMPC ввів спрощену процедуру реєстрації ЛЗРП в країнах-членах ЄС, яка дозволяє подати матеріали реєстраційного досьє без відомостей та документів щодо доклінічних досліджень та клінічних випробувань стосовно ефективності та безпеки за умови, що є достатні докази використання ЛЗРП у медичній практиці протягом періоду, щонайменше, 30 років, в тому числі, 15 років в $€$ С.

Прикладом іншого підходу є практика США, де обіг ЛЗРП регулюється відповідно до Акту від 1994 р. щодо добавок здорового раціону. Регулювання здійснює Адміністрація продуктів та ліків США (USFDA). В рамках цього органу діють Центр дослідження та оцінки ліків (CDER) та Центр оцінки та дослідження біопрепаратів (CBER). Перед тим, як будь-який новий синтетичний або рослинний препарат буде схвалений USFDA, необхідно провести ґрунтовні дослідження стосовно того, що лікарський засіб $є$ одночасно безпечним і ефективним. Як результат, ЛЗРП частіше отримують статус харчових добавок, що не вимагає проведення доклінічних досліджень та клінічних випробувань за заздалегідь затвердженим протоколом.

Тому фрактично всі ЛЗРП можуть реалізовуватись у США як харчові або біологічно активні добавки за умови, що АФІ препарату внесено до відповідної монограсрії Фармакопеї. Упаковки з харчовими добавками не можуть містити надписи з рекомендаціями до медичного застосування, а також з попередженнями щодо потенційних ризиків. USFDA застосовує регулювання обігу ЛЗРП у випадках, коли існують значні ризики щодо безпеки, або коли вони мають вагомі покази до медичного застосування. Таким чином, на відміну від лікарських засобів, які повинні пройти усі фрази клінічних випробувань для того, щоби довести свою безпеку та ефективність, більшість рослин та препаратів 3 них продають фрактично без доказових досліджень.

Класифікація продуктів, що містять ЛРС, є компетенцією уповноважених органів окремих держав. Це призводить до ситуації, коли препарат, що містить од- накові АФІ і в тому ж дозуванні, в деяких країнах вважається харчовою добавкою, а в інших лікарським засобом. Класифрікацію продукту визначає спосіб представлення його, як такого, що має властивості для лікування або профрілактики захворювання у людей. Або коли препарат може бути використаним з метою відновлення або корегування певної фрізіологічної фрункції людини шляхом реалізації орармакологічної, імунологічної або метаболічної дії. Ті ж самі рослини можуть використовуватися в обох якостях залежно від дозування та форми. Наприклад, в Нідерландах трави гінкобілоби, валеріани та звіробою продаються як харчові продукти та як лікарські засоби.

Різниця між харчовим продуктом і лікарським засобом $€$ дуже великою з практичної точки зору, оскільки ліки більш жорстко регулюються, ніж харчові продукти. Для того, щоб відрізнити перші від других використовують різні підходи. Наприклад, беруть до уваги вміст активної речовини, як запропоновано у роботі [11]. Якщо цей кількісний вміст буде вище рекомендованої добової дози, тоді продукт має бути віднесений до лікарського засобу. Якщо на рівні рекомендованої дози або нижче - то це харчова добавка. Після визначення статусу препарату на основі ЛРС мають бути встановлені підходи стандартизації ЛРС.

Світові підходи до стандартизації ЛРС. Найважливішим фрактором, що визначає фрактичну якість готових ЛЗРП, вважають якість ЛРС [12, 13]. Етапи стандартизації ЛРС згідно з рекомендаціями ВООЗ наведено на рисунку 1.

Відповідно до міжнародних принципів процес стандартизації ЛРС має спиратися на результати досліджень, стосується трьох основних фармакопейних десрініцій $[13,14]$ та має відповідати на три питання щодо:

1) ідентичності - чи є рослина тою, якою вона повинна бути?

2) чистоти - чи наявні забруднення (ботанічні, мікробіологічні або хімічні забруднення) та чи не перевищують вони визначені ліміти?

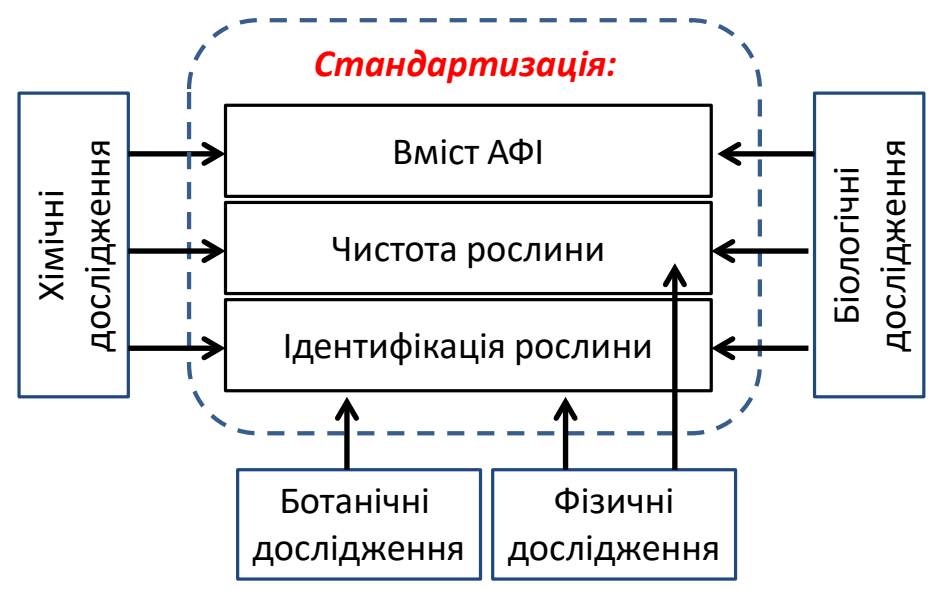

Рис. 1. Схема стандартизації та забезпечення контролю якості ЛРС.

ISSN 2312-0967. Pharmaceutical review. 2017. № 2 
Analysis of drugs

3) вмісту - чи присутні АФІ у визначених концентраційних межах?

Для доведення ідентичності та чистоти рослин існує ряд підходів, основаних на вивченні біологічних, хімічних та фрізичних характеристик. Ідентичність встановлюють шляхом макро- та мікроскопічного вивчення, хоча хвороби рослин інколи ускладнюють ідентисрікацію [14].

Чистота рослин важлива для забезпечення якості, а також тісно пов'язана 3 питанням безпеки лзРП. Для визначення чистоти використовують такі характеристики, як наявність сторонніх органічних речовин, вміст золи та вологи, наявність мікробіологічного забруднення та афрлотоксинів, залишки пестицидів, вміст важких металів, радіоактивне забруднення. Для контролю використовують сучасні методи аналізу (хроматографрічні, атомно-абсорбційної та атомноемісійної спектрометрії, мас-спектрометричні та ін.) [15-18].

Визначають орієнтовну кількість АФІ, що може бути екстрагованим розчинниками 3 даної кількості ЛРС. Такий аналіз використовується для матеріалів, для яких не існує методик хімічного або біологічного аналізу.

Існує проблема із забезпечення вмісту АФІ визначеної концентрації у вихідній ЛРС. Складний та не завжди вивчений хімічний та біохімічний склад рослин є викликом для розробки нових аналітичних методів діагностики, специфрікації та контролю якості ЛРС, що часто містить більш ніж один АФІ. Наприклад, відома лікарська рослина шоломниця байкальська (Scutellaria baicalensis) містить понад 2000 сполук [2].

Стандартизація спрямована на те, щоби гарантувати незмінний склад усіх компонентів ЛРС [13]. Одним 3 найбільш перспективних підходів до вирішення цієї проблеми вважають створення на основі комбінації хроматографрічних та спектроскопічних даних своєрідних «відбитків» або хімічного профілю рослин одночасно із визначенням хімічних або генетичних маркерів, які в сукупності забезпечать однозначну ідентифрікацію рослини чи сировини з неї. Ці напрями називають хімічна та біологічна «дактилоскопія» [19].

Згідно з настановами ЕMA хімічні маркери - це хімічно визначені складові або групи складових рослин, які важливі для здійснення контролю якості незалежно від того, чи проявляють вони терапевтичний ефект. Відповідно хімічні маркери розділяють на аналітичні (без медичного ефректу) та активні (саме АФІ). Як маркери можуть бути використані навіть токсичні компоненти та вторинні метаболіти рослин.

Аналіз, що базується на хімічних маркерах, має свої обмеження. Маркери визначені не для всіх лікарських рослин. Оскільки генетичний склад $є$ уні- кальним для кожного виду і не залежить від віку, фрізіологічних умов або навколишнього середовища, маркери, засновані на ДНК, також використовуються для диференціації індивідуальних рослин, виявлення рослинних домішок, ідентисрікації внутрішньо- та міжвидових змін.

Таким чином, більш досконалі і складні методи дослідження мають бути залучені для повної стандартизації ЛРС. За умов мінливості ЛРС важливим $€$ процес призначення набору стандартів, власних характеристик та постійних кількісних або якісних параметрів, які разом гарантують якість, ефективність, безпеку та відтворюваність властивостей лРС.

Система забезпечення якості ЛЗРП, прийнята в Україні. На даний час немає офріційних загальновизнаних строгих підходів до створення системи забезпечення якості, що має охоплювати усі елементи, які впливають на якість, ефективність та безпеку лзРП від вирощування ЛРС, розробки лікарських засобів до їх виробництва, контролю якості, зберігання та використання. Ті виробники ЛЗРП, які застосовують на виробництві власні підходи до забезпечення якості, у більшості випадків використовують свій досвід, дані наукових досліджень, документи, що мають рекомендаційний характер.

Такий висновок підкріплює аналіз даних щодо складу ЛЗРП, що наведені в Державному реєстрі лікарських засобів України [6]. Тільки приблизно $25 \%$ виробників ЛЗРП наводять в реєстраційних документах дані стосовно вмісту АФІ. Більшість обмежується назвою рослини. Відомості щодо можливих домішок та інших складових речовин відсутні у відкритих реєстраційних даних.

Аналіз діючих нормативних документів дозволяє проілюструвати взаємозв'язок між елементами системи забезпечення якості ЛЗРП та етапами їх виробництва (рис. 2).

Схема свідчить, що ключовими умовами для отримання якісної продукції $€$ забезпечення отримання якісної ЛРС, а також дотримання вимог GMP на усіх етапах роботи 3 нею.

Висновки. Показано, що найбільш важливими проблемами регулювання обігу ЛЗРП є: створення єдиної класифрікації продуктів, що містять ЛРС; стандартизація ЛРС (розробка нових методів дослідження вихідної ЛРС та забезпечення вмісту у ній АФІ визначеної концентрації); відсутність узгоджених підходів до створення системи забезпечення якості ЛЗРП, що мають охоплювати усі елементи, які вливають на якість, ефективність та безпеку. Побудовано схему, що ілюструє взаємозв'язок між фракторами безпеки та якості і заходами щодо контролю якості та етапами виробництва лікарських засобів рослинного походження.

ISSN 2312-0967. Фармацевтичний часопис. 2017. № 2 


\section{Фактори безпеки та якості $\longrightarrow$ Контроль якості $\longrightarrow$ Етапи виробництва}

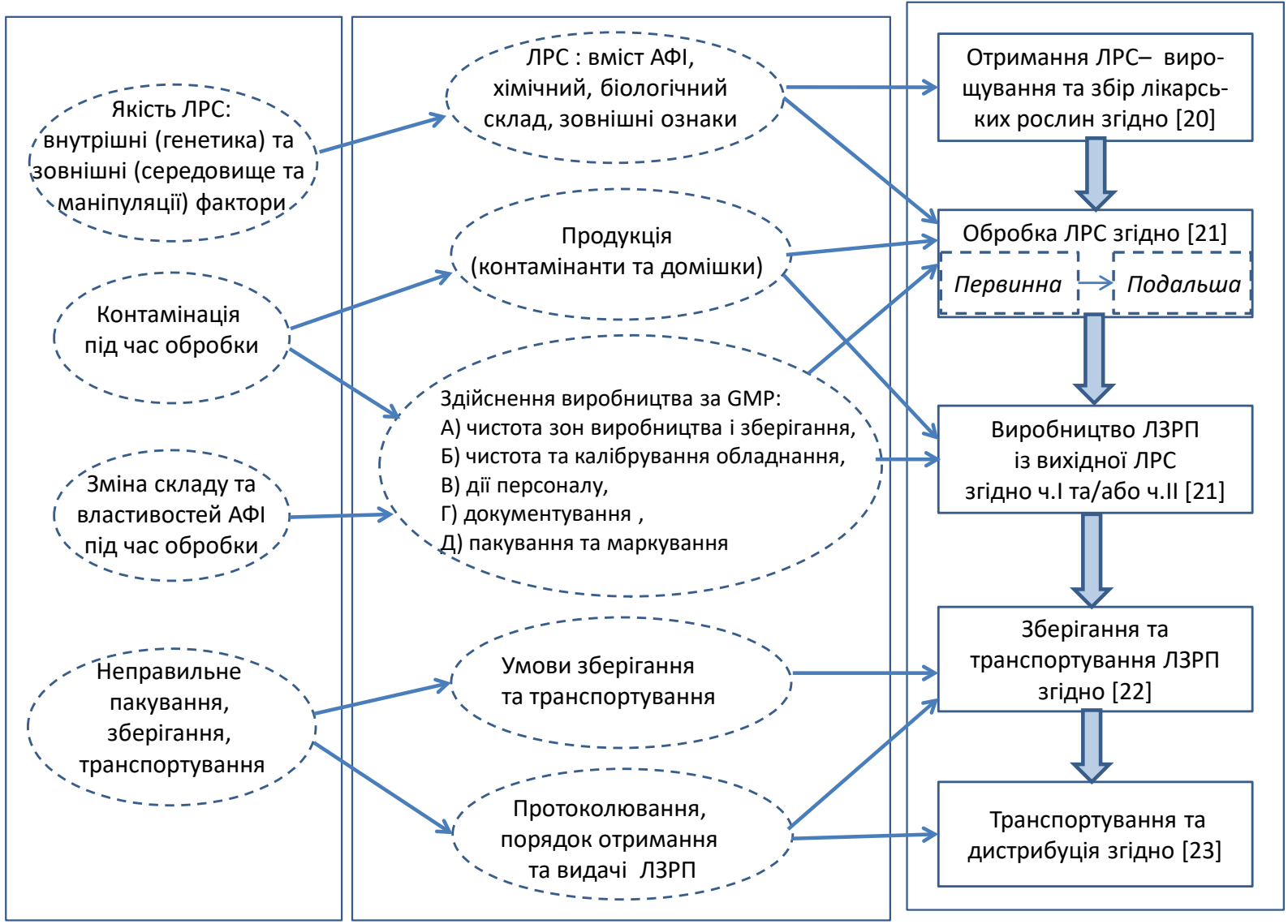

Рис. 2. Елементи забезпечення якості ЛЗРП та основні етапи їх виробництва.

\section{ОБЕСПЕЧЕНИЕ КАЧЕСТВА ЛЕКАРСТВЕННЫХ СРЕДСТВ РАСТИТЕЛЬНОГО ПРОИСХОЖДЕНИЯ: СОСТОЯНИЕ И ПЕРСПЕКТИВЫ}

\section{О. П. Баула, Т. М. Деркач \\ Киевский национальный университет технологий и дизайна derkach.tm@knutd.com.ua}

Цель работы. Анализ современного состояния качества лекарственных средств растительного происхождения, определение проблем, требующих исследования и разработки, и перспективных путей их решения.

Материалы и методы. Лекарственное растительное сырье и лекарственные средства растительного происхождения; системный подход, инфрормационный поиск, статистические методы, обобщение и анализ.

Результаты и обсуждение. Исследованы современные мировые подходы к обеспечению качества лекарственных средств растительного происхождения по сравнению с ситуацией в Украине. Ключевыми фракторами являются обеспечение качества лекарственного растительного сырья за счет его стандартизации, а также соблюдение требований надлежащей производственной практики на всех этапах производства. Построена схема, иллюстрирующая взаимосвязь между фракторами безопасности и качества, мерами по контролю качества и этапами производства лекарственных средств растительного происхождения.

Выводы. Важнейшими проблемами регулирования обращения лекарственных средств растительного происхождения являются: создание единой классисикации продуктов, содержащих лекарственное растительное сырье; стандартизация сырья (разработка новых методов исследования исходного растительного сырья и обеспечение в нем определенной концентрации АФИ); отсутствие согласованных подходов к созданию системы обеспечения качества лекарственных средств растительного происхождения, которые должны охватить все элементы, влияющие на качество, эфффективность и безопасность.

ISSN 2312-0967. Pharmaceutical review. 2017. № 2 
Аналіз лікарських препаратів

Analysis of drugs

Ключевые слова: лекарственное растительное сырье; лекарственные средства растительного происхождения; стандартизация; качество; свойства.

\section{QUALITY ASSURANCE OF HERBAL MEDICINAL PRODUCTS: STATUS AND PROSPECTS}

\section{O. P. Baula, T. M. Derkach}

Kyiv National University of Technologies and Design

derkach.tm@knutd.com.ua

The aim of the work: to analyze the current state of quality assurance of herbal medicines, identify problems that require investigation and development, and describe ways for their solution.

Materials and Methods. Medicinal herbs and herbal medicinal products; systematic approach, information search, statistical methods, generalization, and analysis.

Results and Discussion. The modern world approaches to ensuring the quality of herbal medicines are compared with the situation in Ukraine. The key factors are the quality assurance of medicinal plants using their standardization and compliance with good manufacturing practices at all stages of production. A diagram was constructed to illustrate the relationship between, on the one hand, the factors of safety and quality, and, on the other hand, measures for quality control and phases of herbal medicine production.

Conclusions. The major problems of regulation of herbal medicines are as follows: the creation of a unified classification of products containing medicinal herbs; standardization of raw materials, including development of new research methods and providing there certain APIs concentrations; lack of consistent approaches to establishing a system of quality assurance of herbal medicines that should cover all elements, affecting the quality, efficiency and safety.

Key words: medicinal herbs; herbal medicinal products; standardization; quality; quality assurance.

\section{Список літератури}

1. Мудрак І. Г. Аналіз динаміки доказових даних про лікарські рослинні засоби у базі Кокрана / І. Г. Мудрак, О. М. Заліська // Фармацевт. часоп. - 2011. - № 3. -C. $75-78$

2. Sahoo N. Herbal drugs: Standards and regulation / N. Sahoo, P. Manchikanti, S. Dey // Fitoterapia. - 2010. Vol. 81. - P. 462-471.

3. Наукове обґрунтування доцільності подальшого включення лікарських засобів рослинного походження до державного фрормуляру лікарських засобів / Х. І. Макух, Т. Б. Ривак, А. Б. Зіменковський [та ін.] // Фармацевт. журн. - 2010. - № 1. - С. 31-35.

4. Гудзенко А. В. Вітчизняний ринок багатокомпонентних лікарських засобів рослинного походження: аналіз стану, структура та перспективи розвитку / А. В. Гудзенко, О О. Цуркан, Т. В. Ковальчук // Фармацевт. журн. - 2012. - № 1. - C. 8-12.

5. Overview on External Contamination Sources in Traditional Chinese Medicines / J. Xue, D. J. Liu, Sh. Chen [et al.] // Mode. Tradit. Chin. Med. Mater. Med. - 2008. Vol. 10, No1. - P. 91-96.

6. Державний реєстр лікарських засобів. - [Електронний ресурс]. - Режим доступу: http://www.drlz.com.ua/.

7. Сметаніна К. І. Рослинні ліки. Проблеми розробки лікарських засобів рослинного походження / К. І. Сметаніна // Фармацевт. часоп. - 2011. - № 2. C. $95-98$.

8. Kunle O. F. Standardization of herbal medicines - A review / O. F. Kunle, H. O. Egharevba, P. O. Ahmadu // Int. J. Biodivers. Conserv. - 2012. - Vol. 4, No. 3. - P. 101-112.
9. World Health Organization. WHO guidelines for assessing quality of herbal medicines with reference to contaminants and residues; 2007. [Електронний ресурс]. - Режим доступу: http://www.drlz.com.ua/.

10. Functional foods and dietary supplements: Products at the interface between pharma and nutrition / S.R. Eussen, $\mathrm{H}$. Verhagen, O.H. Klungel, [et al.] // Euro. J. Pharmacol. 2011. - Vol. 668. - P. S2-S9.

11. Use of botanicals in food supplements. Regulatory scope, scientific risk assessment and claim substantiation / P. Coppens, L. Delmulle, O. Gulati [et al.] // Ann. Nutr. Metab. - 2005. - Vol. 50. - P. 538-554.

12. Yadav P. Quality Control Parameters for Medicinal Plants, an Overview / P. Yadav, P. K. Prajapati // Asian J. Biomed. Pharm. Sci. - 2011. - Vol. 1, No. 5. - P. 12-16. 13. Choudhary N. An overview of advances in the standardization of herbal drugs / N. Choudhary, B. Singh Sekhon // J. Pharm. Educ. Res. - 2011. - Vol. 2, No. 2. - P. 55-70.

14. Kaushik D. Current issues in Authentication and Quality control of Natural Products / D. Kaushik, M.K. Pandey, A. Sharma // Res. Plant. Biol. - 2014. - Vol. 4, No. 5. P. 57-64.

15. Державна фрармакопея України 2.0: в 3-х т. / Державне підприємство «Український науковий фармакопейний центр якості лікарських засобів». - 2-е вид. - Харків : Державне підприємство «Український науковий фрармакопейний центр якості лікарських засобів», 2014.- Т.1 - 1127 с.

16. Деркач Т. М. Реалізація проблемного підходу у навчанні аналітичній хімії майбутніх срахівців для

ISSN 2312-0967. Фармацевтичний часопис. 2017. № 2 
фрармацевтичної галузі / Т. М. Деркач // Сучасні досягнення фрармацевтичної технології та біотехнології : зб. наук. пр. - Харків : Вид-во НФаУ, 2016. - С. 194-197. 17. Настанова СТ-НМОЗУ 42-3.9: 2014 «Лікарські засоби. Домішки в нових лікарських речовинах та нових лікарських препаратах». - К. : МОЗ України. - 2014. - 27 с.

18. Изменение подходов к нормированию содержания тяжелых металлов в лекарственном растительном сырье и лекарственных растительных препаратах (обзор) / Н. Е. Кузьмина, В. М. Щукин, Е. Ю. Северинова [та ін.] // Хим.-фрармац. журн. - 2015. - Т. 49, № 7. - С. 52-56.

19. Future Trends in Standardization of Herbal Drugs I P.H. Nikam, J. Kareparamban, A. Jadhav, V. Kadam //
J. Appl. Pharm. Sci. - 2012. - Vol. 2, No. 6. - P. 38-44.

20. Настанова СТ-Н МОЗУ 42-4.5:2012. Лікарські засоби. Належна практика культивування та збирання вихідної сировини рослинного походження

21. Настанова СТ-Н МОЗУ 42-4.0:2016 Лікарські засоби. Належна виробнича практика - К. : МОЗ України. 2016. - 335 c

22. Настанова СТ-Н МОЗУ 42-5.1:2011 Лікарські засоби. Належна практика зберігання - К. : МОЗ України. - 2011. $-19 \mathrm{c}$.

23. Настанова СТ-Н МОзУ 42-5.0:2014 Лікарські засоби. Належна практика дистрибуції - К. : МОЗ України. 2014. $-41 \mathrm{c}$

\section{References}

1. Mudrak IH, Zaliska OM. [Analysis of evidential information about herbal medicines in Cochrane database] Farmatsevt chasop. 2011;3: 75-8. Ukrainian.

2. Sahoo N, Manchikanti P, Dey S. Herbal drugs: Standards and regulation. Fitoterapia. 2010;81: 462-71. doi:10.1016/j. fitote.2010.02.001

3. Makukh Khl, Ryvak TB, Zimenkovskyi AB, Morozov AM, Dumenko TM. [Scientific rationale of expedience for further include of herbal medicines to the public formulary of medicinal products]. Farmatsevt zhurn. 2010;1: 31-5. Ukrainian.

4. Gudzenko AV, Tsurkan OO, Kovalchuk TV. [Domestic market of multicomponent herbal medicines: analysis of state, structure and development prospects]. Farmatsevt zhurn. 2012;1: 8-12. Ukrainian.

5. Xue J, Liu DJ, Chen Sh, Liao JH, Zou ZM. Overview on External Contamination Sources in Traditional Chinese Medicines. Mode Tradit Chin Med Mater Med. 2008;10(1): 91-6. Available from: http://dx.doi.org/10.1016/S18763553(09)60001-6.

6. State Register of Medicinal Products. Available from: http://www.drlz.com.ua/. Ukrainian

7. Smetanina KI. [Herbal drugs. Development problems of herbal medicines]. Farmatsevt chasop. 2011;2: 95-8. Ukrainian.

8. Kunle OF, Egharevba HO, Ahmadu PO. Standardization of herbal medicines - A review. Int J Biodivers Conserv. 2012;4(3): 101-12. DOI: 10.5897/IJBC11.163

9. World Health Organization. WHO guidelines for assessing quality of herbal medicines with reference to contaminants and residues; 2007. Available from: http://www.drlz. com.ua/.http://apps.who.int/medicinedocs/index/assoc/ s14878e/s14878e.pdf

10. Eussen SR, Verhagen $\mathrm{H}$, Klungel $\mathrm{OH}$, Garssen $\mathrm{J}$, van Loveren $\mathrm{H}$, van Kranen $\mathrm{HJ}$, et al. Functional foods and dietary supplements: Products at the interface between pharma and nutrition. Euro J Pharmacol. 2011;668: S2-S9. DOI:10.1016/j.ejphar.2011.07.008

11. Coppens P, Delmulle L, Gulati O, Richardson D, Ruthsatz $\mathrm{M}$, Sievers $\mathrm{H}$, et al. Use of botanicals in food supplements. Regulatory scope, scientific risk assessment and claim substantiation. Ann Nutr Metab. 2005; 50: 538-54. DOI: $10.1159 / 000098146$

12. Yadav P, Prajapati PK. Quality Control Parameters for

Medicinal Plants, an Overview. Asian J Biomed Pharm Sci. 2011; 1(5): 12-6.

13. Choudhary N, Singh Sekhon B. An overview of advances in the standardization of herbal drugs. J Pharm Educ Res. 2011;2(2): 55-70.

14. Kaushik D, Pandey MK, Sharma A. Current issues in Authentication and Quality control of Natural Products. Res Plant Biol. 2014; 4(5): 57-64.

15. Ukrainian Scientific Pharmacopoeial Center for Quality of Medicines. State Pharmacopoeia of Ukraine [Державна Фармакопея України]. 2nd ed., Vol. 1. Kharkiv: Ukrainian Scientific Pharmacopoeial Center for Quality of Medicines; 2014. Ukrainian.

16. Derkach TM. [Implementation of problem-solving approach in analytical chemistry learning of future specialists of pharmaceutical industry] In: Chernykh VP, Hladukh YeV, Strelnykov LS, [et al.] editors. Modern achievements of pharmaceutical technology and biotechnology: Proceedings of the $5^{\text {th }}$ International Research and Training Conference Modern achievements of pharmaceutical technology and biotechnology, 2016 Nov 18; Kharkiv. Kharkiv: National Pharmaceutical University; 2016. p. 194-197. Ukrainian.

17. Guideline ST-NMOZU 42-3.9: 2014 Medicinal products. Impurities in new medicinal substances and new medicinal products. [Настанова СТ-НМОзУ 42-3.9: 2014 Лікарські засоби. Домішки в нових лікарських речовинах та нових лікарських препаратах]. Kyiv: Ministry of Health of Ukraine; 2014. Ukrainian.

18. Kuz'myna NE, Shchukyn VM, Severynova EYu, Yakshyr VA, Merkulov VA. [Change in approaches to regulation of heavy metal content in medicinal plant raw materials and herbal products (a review)]. Khim-farm zhurn. 2015;49(7): 52-6. Russian.

19. Nikam PH, Kareparamban J, Jadhav A, Kadam V. Future Trends in Standardization of Herbal Drugs. J Appl Pharm Sci. 2012; 2(6): 38-44. DOI: 10.7324/JAPS.2012.2631

20. Guideline ST-NMOZU 42-4.5:2012 Medicinal products. Good growth and collection practice for herbal starting materials. [Настанова CT-H МОзу 42-4.5:2012. Лікарські засоби. Належна практика культивування та збирання вихідної сировини рослинного походження]. Kyiv: Ministry of Health of Ukraine; 2012. Ukrainian.

21. Guideline ST-NMOZU 42-4.0:2016 Medicinal products. Good manufacturing practice. [Настанова СТ-Н мОзу

ISSN 2312-0967. Pharmaceutical review. 2017. № 2 
Аналіз лікарських препаратів

\section{Analysis of drugs}

42-4.0:2016 Лікарські засоби. Належна виробнича практика]. Kyiv: Ministry of Health of Ukraine; 2016. Ukrainian.

22. Guideline ST-NMOZU 42-5.1:2011 Medicinal products. Good storage practice. [Настанова CT-H МОЗУ 42-5.1:2011 Лікарські засоби. Належна практика зберігання]. Kyiv: Ministry of Health of Ukraine; 2011. Ukrainian.

23. Guideline ST-NMOZU 42-5.0:2014 Medicinal products. Good distribution practice. [Настанова CT-Н МОЗУ 42-5.0:2014 Лікарські засоби. Належна практика дистрибуціï]. Kyiv: Ministry of Health of Ukraine; 2014. Ukrainian. 